\title{
Challenges of Microfinance Access in Nigeria: Implications for Entrepreneurship Development
}

\section{Ogujiuba Kanayo}

Research Division, National Institute for Legislative Studies, Abuja-Nigeria Department of Statistics and Population Studies University of Western Cape, Cape Town-South Africa E-mail:kannyog@gmail.com

Fadila Jumare

Research Division, National Institute for Legislative Studies, Abuja-Nigeria

Stiegler Nancy

Department of Statistics and Population Studies University of Western Cape, Cape Town-South Africa

\section{Doi:10.5901/mjss.2013.v4n6p611}

\begin{abstract}
Small and Medium Enterprises (SMEs) are increasingly being accepted as valuable platforms to create jobs and improve livelihoods. The Nigerian government has enacted favorable laws and regulations on contracts, leasing, and corporate tax to encourage the development of SMEs. Nonetheless, many entrepreneurs in Nigeria cannot access loans given the high levels of poverty. The paper argues that microenterprise finance cannot be financially viable because small loans are too costly to administer and the profits from such lending too meager to permit profitability. Based on content analysis of available literature, it is found that microfinance institutions have collapsed in Nigeria due to poor loan quality, default in loan repayment, high transaction costs, widespread delinquency, and management deficiencies. Given these challenges, the paper recommends savings by microfinance institutions and measures from successful initiatives from countries such as Indonesia and Bangladesh. These will enable microfinance institutions to be self-sustaining and to increase outreach.
\end{abstract}

Keywords: Microfinance, Poverty, Small and Medium Enterprises, profitability

\section{Introduction}

The unemployment problem in Nigeria has remained persistent resulting in deterioration of welfare of people and therefore little prospect for measurable development in the country. Based on data provided by the Nigerian Bureau of Statistics (NBS) (2011), the unemployment rate in Nigeria has increased to 23.9\% in 2011 compared to 21.1\% in 2010 and $19.7 \%$ in 2009. In order to boost employment in Nigeria, the government has focused on the area of Credit Delivery to the Poor and Small and Medium Enterprises (SMEs). Efforts in this respect include developing policies and creating institutions for mobilizing and deploying capital funds to SMEs. These are found in various Governments' key development strategies such as the National Economic Empowerment Strategy (NEEDS), Seven (7) Point Agenda and the current Transformation Agenda. A coordinated implementation of NEEDS is expected to have created at least 7 million new jobs (National Planning Commission, 2004) but this has not materialized. Over the years, microfinance has emerged as an effective strategy for employment creation and poverty reduction and across developing countries, micro, small and medium enterprises are turning to Microfinance Institutions (MFIs) for an array of financial services. In many countries, these MFIs have emerged as a response to address unemployment and the failure of state-led and mainstream formal financial system to reach the poor who were not seen as bankable clients.

The Nigerian government has institutionalized microfinance as the practice of collaborative provision of financial services such as credits (loans), savings, micro-leasing, micro-insurance and payment transfers to economically active poor and low income households. This is to enable them engage in income generating activities or expand their small 
businesses (Irobi, 2008). However, the impact of this intervention on rural communities is yet to be ascertained. Despite commitment by the Nigerian government in the abovementioned approaches, majority of the SMEs are unable to access loans from MFIs thus failing to obtain start-up capital for business purposes. This is because the microfinance sector is fraught with many challenges, with evidence showing that the MFIs experience problems relating to information asymmetry and risk perceptions ${ }^{1}$. Moreover, government initiatives were not successful because MFIs are facing challenges with regards to promoters' low entrepreneurial skills. There is also the problem of lending to poorly packaged projects making it difficult to achieve the desired outreach levels (Akinlua \& Akintunde, 2008).

In addition, majority of the people engaged in SMEs are among the poor and low income groups in Nigeria and are found in the rural areas. As observed by Soludo (2008), banking services were only available to about $40 \%$ of the population in 2008 , whereas more than $70 \%$ of the poor did not have access to formal finance in the same year. Consequently, poverty levels continued to worsen from 68.7 million people in 2003/2004 to 112.519 million in 2010 (NBS, 2011). These poor people do not have access to institutional credit mainly because they are not considered credit worthy hence they cannot borrow from banks or formal financial institutions. Furthermore, money markets including the traditional moneylenders provide loans but charge very high interest rates which rural dwellers cannot afford (Nosiru, 2010:291). This paper discusses the wide range of microfinance sources in Nigeria, their features and relevance to the development of SMEs in Nigeria. Thereafter, the paper evaluates the impact (in terms of outreach and sustainability of MFIs) in Nigeria in providing the needed succor to their target group. The paper further identifies emerging challenges and then provides recommendations for adoption based on successful practices in countries like Indonesia and Bangladesh.

\section{Models of Microfinance Institutions in Nigeria}

Under the Rural Banking Programme of the Central Bank of Nigeria (CBN), Universal Banks were required to establish a specified number of branches in identified rural locations. A major setback to rural banking was the liquidation of many regional banks between 1993 and 2003, without regard to their social function of providing banking to the poor (Adeyemi, 2008). The People's Bank was established in 1989 as a deposit taking and lending institution for the poor by the Federal Government. Although it operated through both urban and rural branches, it did not make much impact because it was bogged down by bureaucracy of government. Community Banks were licensed in the 1990s and were conceived as unit branches/community owned institutions providing non-sophisticated services to local residents. The incentive for their establishment given by the Federal Government was 100\% matching grant for a community thus raising the minimum capital of N0.25 million². Moreover, the Nigerian government has supported a number of programs focused on SMEs. This includes the National Economic Reconstruction Fund (NERFUND), Small and Medium Enterprise Equity Investment Scheme (SMEEIS) and the Small and Medium Enterprise Development Agency of Nigeria (SMEDAN) established in 1989, 2001 and 2003 respectively.

The first programme NERFUND is an apex credit delivery system to channel credit to SMEs through selected participation banks. For its operation, NERFUND obtained equity capital and soft naira loans from the Federal Government and foreign lines of credit from the African Development Bank (Oteh, 2009). The second Programme SMEEIS, requires all banks in the country to put aside $10 \%$ of their profit before tax into a fund for equity investment in SMEs. As such, the universal banks are providing microfinance either through their rural and urban branches or through independent subsidiaries such as the SMEEIS. By 2007, the fund had accumulated over N40 billion, although only 40\% of these funds had been used and for only 200 projects across the country. Thirdly, SMEDAN has been in the business of fostering the growth of SMEs in Nigeria. It was established to promote the development of SMEs with the objective of establishing a structured and efficient micro, small and medium enterprise sector that will enhance sustainable economic development in Nigeria. Since 2003 when it was set up, it has established business and development centers and provided advisory services on access to trade finance. SMEDAN has also organized seminars and workshops at both local and international levels and encouraged the formation, registration and cooperation of SME business associations. In their study on problems of SME programmes in Nigeria, Adejumo \& Olaoye (2012) conclude that the roles of these programmes were limited. Thus NERFUND was unable to on-lend enough funds to the participating banks to back up approved projects of SMMEs.

\footnotetext{
1 These inhibiting factors are reflected in non-repayment of loans and other administrative problems.

2 The minimum capital for Community Banks was eventually raised to N5 million and later to N20 million in 2005.
} 
There is also the Nigerian Agricultural Cooperative and Rural Development Bank (NACRDB) formerly known as Nigerian Agricultural and Cooperative Bank (NACB) established in 1973. This acted like a Development Finance Institution (DFI), extending loans for agricultural development to both small and large scale farmers and to state governments for on-lending to farmers. The Agricultural Credit Guarantee Scheme Fund (ACGSF) was set up in 1978 and designed to reduce the risks involved in agricultural lending by banks which the CBN regulates. It guarantees up to $75 \%$ of the principal in the case of default due to natural events beyond the control of the farmer.

Modern microfinance in Nigeria began as non-profit institutions initiated strategies to address poverty. Over the years, a significant number of NGOs complemented government efforts in microfinance by adopting the extension of microcredit as part of their mandates. The Country Women Association of Nigeria (COWAN) for example established a combination of traditional thrift and credit system known as African Traditional Responsive Bank (ATRB). The Nsukka United Self-Help Organization (NUSHO) in the early 1980s through its savings and credit scheme, organized training/workshop and programmes on credit management for beneficiaries and staff on a yearly basis. Lastly, an institution named Lift Above Poverty Organization (LAPO) was founded, in the late 1980s to provide rural credit plus programmes. Adamu (2007) observed that these MFIs have grown phenomenally, driven largely by expanding informal sector activities and the reluctance of commercial banks to fund emerging government supported cooperatives without collateral requirement and stringent registration processes which majority of the poor cannot fulfill. In response to this, poor households have developed a wide variety of informal community based arrangements to meet their financial needs (Majeha \& Nwachukwu, 2008). Informal sources of finance comprise savings and credit associations including moneylenders which have been providing financial intermediation even before the emergence of semi-formal or formal sources. While acknowledging the prominence of loans among family and friends, Strickland, a British cooperative expert examined the esusu as a possible basis for modern cooperative societies in Africa (Seibel 2006:3). These arrangements known as Rotating Savings and Credit Associations (RoSCA) among the Yorubas in Western Nigeria operate under different names: Etoto for the Igbos in the East and adashi for the Hausas in Northern Nigeria (CBN, 2000).

Numerous adaptations and innovations have sprung from the RoSCA one of which is the transformation into nonrotating savings associations with a permanent loan fund (Siebel 2006:3). All types of cooperatives have regular/compulsory savings by members as one of their goals, while thrift and credit societies combine regular savings of members with lending. While credit cooperatives and institutions have formal constitutions and a degree of legal status, ROSCAs are simpler and built on informal understandings among friends and acquaintances (Beatrice-Aghim \& Mordoch 2005:58). The key features of informal microfinance schemes are savings and credit components, informality of operations and higher interest rates in relation to the formal banking sector (Majeha \& Nwachukwu, 2008). Notwithstanding their high interest rates, groups like ROSCAs and credit cooperatives can help reduce costs, mobilize funds, improve monitoring and deploy informal-based enforcement mechanisms (Beatrice-Aghim \& Morduch, 2005:58). According to these authors, they also predict the limits to group lending and shed light on savings constraints. Another distinguishing feature of classical microfinance practice is its disregard for tangible collateral requirement. In credit cooperatives, pledged collateral is unnecessary as motivation to meet repayment obligation can be created by other means. These include peer group guarantees which ensure effective loan utilization; monitoring and client friendly practices (prompt approval of larger subsequent loans and convenience of access). Clients in most cases have adequate knowledge of members of their credit group, their character and debt absorptive capacity.

From the forgoing discussion, it can be deduced that attempts at using such programs and institutions as NACB, the Rural Banking Schemes and others had not produced the desired impact on microfinance in the past. An overview of the performance of the micro enterprises in Nigeria indicates that previous policies made limited impact on the micro enterprises sector as observed by Akanji (2006). Thus, in 2005, CBN launched the Microfinance Policy Guidelines for Nigeria, which seeks to commercialize the business of microfinance. The new policy set a minimum capital requirement of N20 million for MFBs and required all existing community banks to convert to MFBs by December 31, 2007. The microfinance and supervisory framework issued by the CBN in 2005 sought to encourage the development of SMEs and empower low income groups in Nigeria.

According to the CBN (2005), the policy provides for the setting up of private sector driven MFBs to:

- Provide services for poor and low income groups;

- Cover the majority of the poor but economically active population by 2020; including the following targets:

- Increase the share of micro credit as a percentage of total credit to the economy from 0.9 percent in 2005 to at least 20 percent in 2020;

- Increase the share of micro credit as a percentage of GDP from 0.2 percent in 2005 to at least 5 percent in 2020; 
- Promote the participation of at least two-thirds of state and local governments in micro credit financing by 2015;

- Improve women's access to financial services by $5 \%$ annually; and

- Increase the number of linkages among universal banks, development banks, specialized finance institutions and microfinance banks by 10\% annually (Iganiga 2008:91)

The launching of the Microfinance Guideline in 2005, creating microfinance banks (MFBs) and directing community banks to convert to MFBs by December 31, 2007 ensured that over 700 MFBs are in existence and many more are in advanced stages of licensing.

\section{Microfinance and Enterprise Development}

As of May 30th 2008, a total of 768 microfinance banks have been licensed in Nigeria (CBN, 2008). The geographical distribution is shown below:

Table 1: Distribution of Microfinance Banks May 2008

\begin{tabular}{|l|c|c|}
\hline Geo-political Zone & Number of MFBs & Percentage of Total \\
\hline North-West & 56 & 7.3 \\
\hline North-Central & 101 & 13.2 \\
\hline North-West & 30 & 3.9 \\
\hline South-West & 305 & 39.7 \\
\hline South-South & 110 & 14.3 \\
\hline South-East & 166 & 21.6 \\
\hline Total & 768 & 100.0 \\
\hline
\end{tabular}

Source: CBN, (2008). The Nigerian Microfinance Newsletter, Vol. 6, January-June 2008.

A review of the distribution of Microfinance Banks in the twelve most populous states of the Federation as at 31st Oct, 2011 revealed that while the most populous state in the Federation, Kano State (according to 2006 census) had just 7 Microfinance Banks (MFBs), the second most populous state, Lagos State had 178 MFBs. Also the 11th most populous state, Borno State had only 4 MFBs. Delta State which was the twelfth most populous state had 39 MFBs. Currently, a total of 877 MFBs are in operation in Nigeria even after the liquidation of 103 of them in September 2010.

The skewed distribution of MFBs in Nigeria is capable of limiting access of a vast majority of the economically active poor to credit. Even in those parts of the country with sizable numbers of MFBs, most of the institutions are located in urban places to the neglect of the rural areas because of pure profit making considerations. Notwithstanding the uneven distribution of the MFBs in the country, the astronomical increases in their numbers had led to heightened awareness of the potentials that microfinance banking holds for economic growth and development amongst stakeholders such as government regulatory authorities, investors, development partners, financial institutions, technical assistance providers and donor agencies.

Based on results from empirical studies, it is evident that microfinance can and does improve the social and economic well-being of the poorest population by increasing income and reducing vulnerability. Using statistical methods to assess the impact of microfinance in three Bangladesi programs, Khandker (1998) found that every additional taka lent to a woman adds additional 0.18 taka to her annual household expenditure. Similarly, in an updated study using panel data in Bangladesh, Khandker (2005), found out that each additional 100 taka of credit to women increase total annual household expenditures by more than 20 taka.

Some authors have challenged the positive effects of microfinance on poverty alleviation. Hulme \& Mosley (1996) while acknowledging the role microfinance can have in helping reduce poverty concluded from their research that "most contemporary schemes are less effective than they might be". They stated that microfinance is not a panacea for poverty alleviation and that in some cases the poorest people have been made worse off by microfinance. The conservatives view microfinance as social liability which consumes scarce resources without significantly effecting long term outcomes. Other critics argue that the small enterprises supported by microcredit programs have limited potential to grow and so have no sustained impact on the poor. They contend that these "microfinance programs rather make the poor economically dependent on the program itself" (Bouman and Hospes, 1994). Hence, even if the programs are able to 
reach the poor, they may not be cost-effective and hence worth supporting as a resource transfer mechanism. More troubling, according to Chowdhury (2009) is the finding that a vast majority of those with starting incomes below the poverty line actually ended up with less incremental income after getting micro-loans, as compared to a control group which did not get such loans. The findings from these studies imply that it is only borrowers above poverty lines who can do well with microfinance and enjoy sizeable positive impacts meaning that poor households do not benefit from microfinance (Ifelunini \& Wosowei, 2012).

Moreover, a study of microfinance and agricultural productivity in Ogun State, Nigeria revealed that although microfinance increased productivity of farmers in the study area, farmers with access to such facilities have not made a justifiable utilization of the credits from microfinance banks. Most of the credits were obtained through relatives and farmer's cooperatives (Nosiru, 2010:295) indicating limited impact on the microfinance sector. Another study carried out by Enhancing Financial Innovation and Access (EFinA) in August 2010 revealed that 39.2 million representing 46.3\% of the adults in Nigeria were excluded from financial services. Among the 53.7 percent that had access, 36.3 percent derive their financial services from the formal financial institutions while 17.4 percent exclusively patronized the informal sector. Also the results of the survey revealed that Nigeria was lagging behind South Africa, Botswana and Kenya with 26 percent, 33 percent and 32.7 percent financial exclusion rate respectively. Therefore, while some portray microfinance as an instrument that empowers the poor, others negate this opinion, thus conceptualizing microfinance as a social liability. The question therefore is whether microfinance can reduce poverty while still maintaining the sustainability of the Microfinancial institutions.

Despite developing an appropriate policy and regulatory framework for the operations of MFIs in Nigeria, some studies have revealed that the number of beneficiaries of microfinance banks is an insignificant proportion of the people in need of microfinance services. Notwithstanding the modest gains recorded by MFBs in Nigeria, the poverty challenge in the country remains daunting such that many of the disadvantaged and economically active poor remain financially excluded. As at 2008 when the country's population was over 140 million and over 70\% lived below poverty line, it was estimated that formal MFBs only serviced less than one million clients (Irobi, 2008). Many micro entrepreneurs still lacked access to credit thereby impeding economic growth and economic development. A study conducted by Enhancing Financial Innovation and Access (EFinA) in 2010 indicated that 3.2 million Nigerians (representing $3.8 \%$ of the adult population) had a Microfinance bank of which $57.9 \%$ were males and $42.1 \%$ were females while 1.8 million Nigerians ( $2.1 \%$ of the adult population) used their MFB account as their main bank account.

The major challenges faced by microfinance institutions in Nigeria include:

- Communication gaps and inadequate awareness;

- Inadequate donor funding;

- Less attention on financial sustainability of MFls;

- Lack of adequate loan or equity capital to increase loan-able funds;

- Limited support for human and institutional capacity building; and

- Lack of standardized reporting and performance monitoring system for MFIs (Irobi, 2008).

Outreach and uncertainty of Agricultural income are the major challenges of the microenterprise sector in Nigeria. Ojo, (2009:30) cites that one of the most common challenges for small business is the inability to obtain loans at reasonable interest rates. Although informal commercial moneylenders provide important financial services to the poor with lower transaction costs of obtaining loans than MFIs, the challenge is that they typically charge very high interest rates to low-income borrowers in Nigeria.

Unless micro lenders can charge interests that are well above average bank loan rates, they cannot cover their costs. Their growth and sustainability will be limited by the scarce and uncertain supply of subsidized funding. MFBs in Nigeria are restrained by the interest rates they charge because of the perception that microfinance is a philanthropic activity. Based on these views, it is noted that it costs much more to make many small loans than a few large loans. Consequently, many MFBs in Nigeria were found to have suffered total erosion of their capital base and dissipation of depositors' funds resulting from very high levels of non-performing loans (NPLS) and or insider abuse. This culminated in negative shareholders' funds accompanied by losses and negative capital Adequacy ratio (CAR) which was far below the prescribed minimum levels. In response to this, the CBN had to revoke the operating licenses of one hundred and 101 Microfinance Banks by December, 2010, five years after the formulation of the Microfinance Policy.

In addition, many of the MFBs were unable to meet matured obligations and had closed shop, a situation which had jeopardized depositors' funds in the affected institutions. This is capable of ultimately eroding the safety and credibility of the microfinance sub sector, if it remains unchecked. While non-bank financial intermediaries, such as micro credit institutions, could play a greater role in lending money to the smaller SMEs, they do not have the resources to 
monitor their customers when they expand (Oteh, 2009:31). Their main sources of capital are their retained earnings and informal savings and loan associations, which are unpredictable, not very secure and have little scope for risk sharing because of their regional or sectoral focus (Oteh, 2009:31).

Also, when governments regulate interest rates, they usually set them at levels too low to permit sustainable micro credit administration. A study by Elumilade et al (2010) reveals that micro-enterprises in Osun State of Nigeria were generally inadequately financed due to factors such as unfavorable government policies, money lenders high rate of interest and low personal savings, among others. It also reveals that micro-enterprises are poorly financed because most of the entrepreneurs do not have the necessary documents to access to bank services. It concludes that this low funding is responsible for the poor performance of micro-enterprises in Osun State and Nigeria in general. Another challenge of the subsector is lack of relevant skills. Microfinance banking is different from conventional banking. As earlier indicated, microfinance banking involves the provision of financial services to the lower segment of the market. Microfinance banking, therefore, requires specialized skills which are presently lacking in Nigeria.

Many operators with community banking background in Nigeria still run their businesses as if they were community banks while quite a number of them also see themselves as competitors to Deposit Money Banks. Consequently, they dissipate both depositors' funds and loanable funds by acquiring expensive infrastructure. It is also noteworthy that there are still inadequate funds in the sector for intermediation owing to lack of aggressive savings mobilization, inability to attract commercial capital and the non-establishment of Microfinance Development Funds. Most of the literature on microfinance note the problems countries face in providing microfinance without adequately discussing their impact and solutions. This paper deems it necessary to outline the countries which perform better in outreach and sustainability of MFIs and reveal some of the practices that led to their success.

\section{Policy Implications and Recommendations}

Mergers and Acquisitions as opposed to outright liquidation should be encouraged in the microfinance subsector as obtains in other jurisdictions like Germany where no Cooperative Bank (equivalent of an MFB) has failed in the past 50 years. Asia is the most developed continent of the world in terms of volume of MFI activities. This conclusion is based on an analysis of over 1500 institutions from 85 developing countries. Comparing MFIs in Asia with those in Africa and Latin America in the 1990's, it was noted that Asia accounted for the majority of MFIs, retained the highest volume of savings and credit, and served more members than any other continent. This generalization covers up the wide disparities within the region. It is noted that overall, MFIs have flourished in Asia and that compared to other regions, they exhibit good outreach and high repayment rates. They account for the largest number of borrowers (70 per cent of which are women) and are second only to African MFIs in terms of number of voluntary savers. In terms of impact, size of loans and deposits are often taken as simple indicators of impact on the poor. By these criteria, Asian MFIs have one of the lowest Loan and Savings Balance per Borrower, even after adjusting for GNP per capita, suggesting that they are effectively reaching the poor. The superior performance of such programs as Bank Rakyat Indonesia's (BRI) Unit Desa or Village Bank program in Indonesia, and the Grameen Bank in Bangladesh are frequently cited as evidence that it is possible for microfinance institutions to make small loans to large numbers of poor people in a sustainable manner (Bhatt \& Tand 2001:319). Given that efforts are yet to unleash the potential that Nigeria has to leverage SMEs, the proposals outlined below can harmonize ongoing initiatives:

In order to encourage lending to SMEs, it is necessary for Microfinance institutions to have access to reliable and recent information about clients. Oteh (2009:33-34) maintains that this is a key precursor to lending. Furthermore, a streamlined and transparent calculation method of recovery rate of the microfinance institutions is required to ensure adequate information on defaulting clients. This can be achieved by establishing credit bureaus which adopt and maintain clear and simple accounting standards for lending to SMEs. African countries like South Africa, Kenya and Zambia are already experimenting with innovative financial instruments such as warehouse-receipt financing. This facilitates in guaranteeing loans with agricultural stocks in these countries. Other financial instruments, such as leasing and partnership (sharing risks) with credit cooperatives can reduce risks effectively for credit institutions. Similar to Zambia's agro-food industry, large firms which have greater access to finance can be encouraged to assist SMEs in obtaining export credits and providing other factors of production. These innovative financing mechanisms can help financial institutions choose to whom to lend, by guaranteeing the technical viability of projects, and sometimes providing guarantees.

According to Oteh (2009: 33-34), clusters can be formed to enable member firms seek finance together, provide collective guarantees or even set up their own financial bodies. Experience from SMEs in Asia has shown that the 
relationships formed by these networked firms often make it easier to obtain loans with lower rates of interest. Working together also means that firms can get supplier credit and can borrow from each other. Nigeria can learn from this experience by engaging with trade associations such as the African Venture Capital Association which can play a crucial role in fostering the development in SME networks in Nigeria.

In addition to strengthening financial institutions, a viable strategy would also be to expand the scope of micro credit institutions to offer services to small businesses. Many of these institutions have limited funding and since they rely on deposits that are short term in nature, there are asset and liability constraints for them to convert their deposits into longer term loans. Some institutions are seeking to reduce the financing gaps for their activities by providing loans free of bank charges for a minimum deposit. Novabanco, a microcredit institution in Angola is a good example as it has expanded the scope of its activities in this regard. In addition, it accepts informal guarantees and leverages the long term relationships developed by its loan officers to support small businesses owned by its customers (Awojobi, 2011:64). Other strategies that have been pursued to fill the microfinance financing gap include supporting the growth of smaller commercial banks and rural banks as practiced in Kenya and Ghana respectively. According to Awojobi (2011: 64), commercial banks in many other countries are beginning to set up their micro-credit services to cater for the microenterprise sector.

Due to inadequate information flows, the interaction and inter-relationship of relevant actors in the microfinance sector is minimal. Efforts at the development of the microfinance sector must incorporate arrangements for the process of cooperation and partnership among government, NGOs, credit unions and private lenders. The linkage will enhance efficiency in programme implementation in terms of outreach and credit disbursement. For instance in Pakistan, there were deliberate and comprehensive institutional arrangements for collaboration and co-operation among public sector institutions, private sector organizations, formal banking sector, local communities, NGOs and donor agencies. Adequate incentives were provided to drive the process thus bringing about development to the sector in Pakistan (Olaitan, 2003:37).

If a microcredit institution is to maintain its capacity holdings, it must generate sufficient revenue to meet its operating costs, including the cost of administering loans, mobilizing and training groups, mobilizing funds for on-lending and covering bad debts. Microfinance institutions, especially Grameen Bank, have made a successful breakthrough in reaching the target group mainly because of easy availability of funds and close supervision (Baharet al 2001). Microfinance in Nigeria still holds an enormous potential as sufficient funds could be created beyond access to public savings and donors' funds. This could be through increased government commitment of resources or through institutional arrangements. The institutional arrangement should be such that funds will be managed by an institution empowered to mobilize funds for lending arrangement with MFIs. The institution should also reflect the interest of all stakeholders in governance and management. In Bangladesh, the central financing authority played an effective role in providing sufficient flow of adequate funds in microfinance sector (Awojobi 2011:165).

\section{References}

Adeyemi, K. S. (2008). Institutional reforms for efficient microfinance operations in Nigeria. Central Bank of Nigeria Bullion, 32(1), 26-34. Adejumo, D.G. \& Olaoye, J. A. (2012). Roles and Problems of Small-Scale Business Development Programmes in Nigeria. Available: http://www.ijmbs.com/21/dende.pdf. Accessed November 9, 2012.

Anyanwu, C. M. (2004) Microfinance Institutions in Nigeria: Policy, Practice and Potentials, Paper Presented at the G24 Workshop on Constraints to Growth in Sub Saharan Africa, Pretoria, South Africa, by the Deputy Director Central Bank of Nigeria, November 29-30, 2004

Awojobi, Omotola and Bein, Murad (2010). Microfinancing for Poverty Reduction and Economic Development; a Case for Nigeria. Published in: International Research Journal of Finance and Economics, Vol. 1, No. 72 (11. August 2011): pp. $159-168$.

Bahar, H. (2001) Financing for Micro-Enterprises, Small, Medium-Sized and Cottage Industries: Bangladesh Perspective. Paper presented at the ESCAP-ADB Joint Workshop on Mobilizing Domestic Finance for Development: Reassessment of Bank Finance and DebtMarkets in Asia and the Pacific held in Bangkok, 22-23

Bashir, U. (2008). Overview of Credit Delivery Channels in Nigeria. Bullion Publication of Central Bank of Nigeria, Vol. 32(1), 1-6.

Central Bank of Nigeria, (2005). Microfinance policy, regulatory and supervisory framework for Nigeria. December 2005 Abuja, Nigeria: CBN.

Charles, A. J., Akinlabi, K.J. \& Hamed, B. (2011). Impact of Microfinance on Poverty Alleviation in Nigeria: An Empirical Investigation. European Journal of Humanities and Social Sciences 3(1).

Christen, R., Rhyne, E., Vogel, R., \& McKean, C. (1995). Maximizing the outreach of microenterprise finance: An analysis of successful programs, program and operations. Assessment Report No. 10, United States Agency for International Development, Washington, DC. 
Development Goals (MDGs) in Nigeria Journal of Development and Agricultural Economics Vol. 3(3), pp. 98-106, March 2011

Enhancing Financial Innovations and Access (2010). EFInA Access to financial services in Nigeria 2010 Survey. Available: http://www.efina.org.ng/assets/Documents/EFInAAccessto-Financial-Services-in-Nigeria-2010-surveyKeyFindings.pdf? phpMyAdmin=\%2CWvBxPNpx0z2BcKe8h2UCHJI\%2CXb. Accessed August 2, 2012.

Egwuatu, B. S. C. (2008). Reducing poverty through better credit delivery: The Asian experience. Central Bank of Nigeria Bullion, 32(1), 8-16

Ehigiamusoe, G. (2008). The role of microfinance institutions in the economic development of Nigeria. Central Bank of Nigeria Bullion, 32(1), 17-24

Elumilade, O. O.; Asaolu, T. O., Oladele, P. O. (2010): The evaluation of financing of micro-enterprises in Osun state of Nigeria

Eyo, E.O.: Farmers Liquidity Value for Unused Credit and the Sustainability of Microfinance Schemes in Akwa Ibom State, Nigeria, Journal of Agriculture \& Social Sciences, 2 (2), 79 (2006).

Hulme, D. \& Moore, K. (2006). Why has microfinance been a policy success in Bangladesh (and beyond)?, GPRG-WPS-041, GPRG and ESRC, http://www.gprg.org/pubs/workingpapers/pdfs/gprg-wps-041.pdf

Iganga, B.O. (2007). An Evaluation of Microfinance Policies and Institutions in Nigeria. Department of Economics, Delta State University, Abraka. Union Digest Vol 11 nos 1 \& 2, pp 77-94.

Iganiga, B. O. (2008). Much ado about nothing: The case of the Nigerian microfinance policy measures, institutions and operations. Journal of Social Sciences, 17 (2), 89-101.

Julius , A. A. \& Azeez B. A. 2010 Microfinance and gender in the context of Millennium

Mejeha, R.O. and I.Nwachukwu. (2008). Microfinance Institutions in Nigeria, MPRA Paper, No. 13711.

Nosiru, O.M. (2010). Microcredits and Agricultural Productivity in Ogun State, Nigeria.World Journal of Agricultural Sciences 6(3):290296.

Oji, K. O. (2008). Analysis of the Effects of Policies of Microfinance Institutions on the Technological Capabilities of Micro-borrowers in Nigeria. Central Bank of Nigeria Economic and Financial Review Volume 46(3).

Ojo O. (2009), Impact of Micro Finance on Entrepreneurial Development: A case of Nigeria. A paper presented at the International Conference on economic and administration, organized by the faculty of Administration and Business, University of Bucharest, Romania, 14th-15th November, 2009.

Okojie, C.E.E., A. Monye-Emina, K. Eghafona, G. Osaghae \& J.O. Ehiakhamen (2009). Institutional environment and access to microfinance by self-employed women in the rural areas of Edo state, Nigeria. NSSP Working Paper 03. Available at http://www.ifpri.org/sites/default/files/publications/nsspbp03.pdf Economic and Financial Review

Okpara G. C., (2010). Microfinance banks and poverty alleviation in Nigeria. J. Sustainable Dev. Afr., 12: 177-191.

Olomola, A.S (2002). Social capital, microfinance group performance and poverty implications in Nigeria. Ibadan, Nigeria: Nigerian Institute of Social and Economic Research.

Omobolanle, N. M. (2010). Microcredits and Agricultural Productivity in Ogun State, Nigeria, World Journal of Agricultural Sciences 6 (3): 290-296

Oteh, A. (2009). The Role of Entrepreneurship in Transforming the Nigerian Economy. Seventh Convocation Lecture Igbinedion University, Okada, Edo State $4^{\text {th }}$ December 2009. [Online] Available: http://iuokada.edu.ng/News/Convocation\%20Lecture/ The\%20Role\%20of\%20Entrepreneurship\%20in\%20Transforming\%20the\%20Nigerian\%20Economy.pdf Accessed: May 25 , 2012.

Seibel, Hans Dieter (2006): Upgrading indigenous microfinance institutions in Nigeria: Trials and errors, Working paper / University of Cologne, Development Research Center, No. 2006,4, http://hdl.handle.net/10419/23659

Umar, B.D (2011). The impact of microfinance subsector in promoting financial inclusion in Nigeria. Paper presented at the FICAN conference, Nigeria Deposit Insurance Corporation.

National Bureau of Statistics, (2011). Annual Socio-Economic Report. Available: http://www.nigeriastat.gov.ng/ Accessed October 15, 2012

National Planning Commission, (2004). National Economic Empowerment and Development Strategy 